\title{
HARMONISASI PENGATURAN PEMBERIAN JANGKA WAKTU HAK PAKAI BAGI WARGA NEGARA ASING
}

\author{
Asto Legowo \\ Kantor Advokat Soehartono Soemarto \& Rekan \\ J1. Tidar Sakti No. 18 Malang \\ Email: astolegowo@yahoo.co.id
}

\begin{abstract}
This journal aims to analyze the juridical implications against he disharmony of granting a period of use rights for foreigners in the construction of the positive law in Indonesia, as well as reviewing and analyzing while also finding a formulation that is harmonious to the reconstruction of granting a period of use rights as a dwelling for foreigners to provide legal certainty in the future to come. The journal uses a normative juridical legislation and conceptual approach. The research results have showed that the implications jurisdiction over disharmony granting a period of use rights for foreigners in the construction of the positive law in Indonesia is uncertainty and contrary to the principles of the formation of legislation, one of which embraces about the principle of correspondence between the type and substance that is important in the formation of a legislation. Such legal uncertainty and contradiction of the principles arises from the inconsistencies of use rights and the dualism of extension and renewal process. Further, harmonisation in the reconstruction in the future to come was done with a few point changes and / or adjusting the settings on the granting of a period of use rights for foreigners as shelter administered over 25 (twenty five) years as well as the enactment of setting back the upgrade procedure without knowing the extension procedure in Article 7 of regulation Number 103 of 2015.
\end{abstract}

Key words: disharmoni, land use, residential, foreigner

\begin{abstract}
Abstrak
Tulisan ini bertujuan untuk menganalisis implikasi yuridis terhadap disharmonisasi pemberian jangka waktu hak pakai bagi Warga Negara Asing dalam konstruksi hukum positif di Indonesia,serta mengkaji dan menganalisis yang sekaligus menemukan suatu perumusan yang harmonis terhadap rekonstruksi pemberian jangka waktu hak pakai sebagai hunian bagi Warga Negara Asingdalam memberikan kepastian hukum dimasa yang akan mendatang. Tulisan ini disusun menggunakan metode penelitian yuridis normatif dengan menggunakan pendekatan perundang-undangan dan pendekatan konseptual.Berdasarkan hasil penelitian telah dapat diketahui bahwa implikasi yuridis terhadap disharmonisasi pemberian jangka waktu hak pakai bagi Warga Negara Asing dalam konstruksi hukum positif di Indonesia adalah ketidakpastian hukum bagi Warga Negara Asing dan bertentangan dengan asas-asas pembentukan peraturan perundang-undangan, yang salah satunya menganut tentang asas kesesuaian antara jenis dan materi muatan yang menjadi hal penting dalam pembentukan suatu peraturan perundangundangan, ketidakpastian hukum dan pertentangan asas tersebut muncul akibat adanya inkonsistensi pemberian jangka watu hak pakai dan dualisme proses perpanjangan dan pembaruan. Selanjutnya, Harmonisasi dalam rekonstruksi pemberian jangka waktu hunian
\end{abstract}


bagi Warga Negara Asing dalam konstruksi hukum positif di Indonesia di masa yang akan mendatang dilakuan dengan beberapa point perubahan dan/atau penyesuaian pengaturan mengenai pemberian jangka waktu hak pakai bagi WNA sebagai hunian yang diberikan selama 25 (dua puluh lima) tahun serta pengaturan diberlakukannya prosedur pembaruan tanpa mengenal kembali prosedur perpanjangan dalam Pasal 7 PP Nomor 103 Tahun 2015.

Kata kunci: disharmonisasi, hak pakai, hunian, warga negara asing

\section{Latar Belakang}

Indonesia merupakan negara yang secara geografis sangat strategis karena terletak diantara 2 (dua) benua, yaitu benua Asia dan benua Australia dan 2 (dua) samudra, yaitu Samudra Pasifik dan Samudra Hindia, selain letak yang strategis, Indonesia juga merupakan salah satu negara yang dilewati oleh garis khatulistiwa, yang karenanya iklim di Indonesia sangat mendukung, tanah yang subur dan kaya akan sumber daya alam serta berbagai macam obyek wisata yang tersedia, menjadikan negara Indonesia seringkali menjadi tujuan bagi Warga Negara Asing (selanjutnya disingkat WNA), baik untuk berpariwisata, berinvestasi maupun berdagang, bahkan sebagai rumah tinggal atau sebagai "rumah kedua" bagi beberapa WNA.

Dengan memperhatikan kondisi tersebut di atas, maka seperangkat peraturan yang mengatur kepemilikan rumah tempat tinggal atauhunianbagiWNAyang berada di Indonesia sangat penting dan menjadi urgensi tersendiri yang harus diperhatikan, karena diharapkan aturan tersebut mampu memberikan kepastian hukum mengenai seberapa lama jangka waktu yang diperoleh WNA untuk dapat memiliki hunian di Indonesia.
Sebagai negara yang menganut sistem hukum civil law, maka di Indonesia dikenal adanya kodifikasi terhadap aturan hukum yang berlaku. Kodifikasi hukum ini bertujuan untuk memberikan kepastian hukum, baik bagi Warga Negara Indonesia maupun WNA yang tinggal di Indonesia. Bentuk dari kodifikasi hukum di Indonesia, berupa peraturan perundang-undangan mengenai hak kepemilikan hunian. Sebelum membahas mengenai hunian, maka hal yang perlu diperhatikan adalah mengenai keberadaan dan status tanahnya.Adapun peraturan perundangundangan di Indonesia yang mengatur secara khusus tentang tanah adalah Undang-undang Nomor 5 Tahun 1960 tentang Peraturan Dasar Pokok-pokok Agraria (Lembaran Negara Republik Indonesia Nomor 104 Tahun 1960, Tambahan Lembaran Negara Nomor 2043), (selanjutnya disingkat UUPA).

Pada prinsipnya, UUPA mengatur tentang larangan penguasaan tanah oleh Warga Negara Asing (selanjutnya disingkat WNA). Hal tersebut merupakan cerminan dari asas nasionalisme sebagaimana diatur dalam Pasal 21 ayat 1 UUPA, yang mengatur bahwa "hanya Warga Negara Indonesia yang dapat mempunyai hak milik”. Semangat 
nasionalisme yang tertuang pada Pasal 21 ayat (1) UUPA tersebut telah memberikan hak penuh bagi Warga Negara Indonesia untuk mengelola bumi dan ruang angkasa dengan tidak membedakan antara laki-laki dengan wanita serta sesama Warga Negara Indonesia baik asli maupun keturunan yang dihasilkan dari suatu perkawinan yang sah. Apabila ditelaah lebih mendalam, maka esensi Pasal tersebut bertujuan untuk menjaga agar tanah tetap menjadi hak milik negara atau Warga Negara Indonesia, karena apabila tanah tersebut dikuasai oleh WNA secara penuh atau dengan waktu yang cenderung lama, maka akan dikhawatirkan kesejahteraan rakyat akan berkurang dalam pengelolaan atas tanah.

Berdasarkan pada aturan tersebut, makaWNA tidak diperbolehkan untuk mempunyai hak milik atas tanah di Indonesia, namun demikian, dengan berlakunya UUPA bukan berarti tidak memberikan kesempatan bagi WNA untuk dapat memiliki tanah di Indonesia, dalam hal ini, undang-undang memberikan hak bagi WNA untuk dapat memiliki tanah di Indonesia, tetapi sebatas hanya dengan Hak Pakai dan Hak sewa untuk Bangunan, dalam hal ini secara khusus berupa rumah tempat tinggal atau hunian yang berdiri di atas tanah hak pakai.
Adapun peraturan perundang-undangan yang mengatur tentang kepemilikan rumah tempat tinggal atau hunian yang diperuntukkan bagi WNA yang berada di Indonesia yang dimaksud, dimulai dengan diberlakukannya Peraturan Pemerintah Nomor 41 Tahun 1996 tentang Pemilikan Rumah Tempat Tinggal atau Hunian oleh Orang Asing yang Berkedudukan di Indonesia, yang kemudian peraturan tersebut digantikan karena Peraturan Pemerintah tersebut dianggap sudah tidak mampu lagi mengikuti perkembangan dan pergerakan investasi di Indonesia, yang kemudian diberlakukannya Peraturan Pemerintah Nomor 103 Tahun 2015 tentang Pemilikan Rumah Tempat Tinggal atau Hunian oleh Orang Asing yang Berkedudukan di Indonesia (Lembaran Negara Republik Indonesia Tahun 2015 Nomor 325, Tambahan Lembaran Negara Nomor 5793), (selanjutnya disebut PP Nomor 103 Tahun 2015) yang diundangkan di Jakarta pada tanggal 28 Desember 2015, berdasarkan konsideran PP Nomor 103 Tahun 2015 huruf a sebagai peraturan baru yang berlaku hingga kini. ${ }^{1}$ PP Nomor 103 Tahun 2015 tersebut turut menjelaskan mengenai dasar hukum atas rumah tempat tinggal atau hunian yang dapat dimiliki oleh WNA serta ketentuan lain yang mengikatnya. ${ }^{2}$ WNA hanya diberikan fasilitas

1 Bahwa dalam rangka melaksanakan UU Nomor 5 Tahun 1960 tentang Peraturan Dasar Pokok-Pokok Agraria, dan untuk lebih memberikan kepastian hukum pemilikan rumah tempat tinggal atau hunian oleh orang asing yang berkedudukan di Indonesia, maka Peraturan Pemerintah Nomor 41 Tahun 1996 tentang Pemilikan Rumah Tempat Tinggal atau Hunian oleh Orang Asing yang Berkedudukan di Indonesia perlu diganti;

2 Pasal 2 ayat (1): Orang Asing dapat memiliki rumah untuk tempat tinggal atau hunian dengan Hak Pakai. ayat (2): Orang Asing yang dapat memiliki rumah tempat tinggal atau hunian sebagaimana dimaksud pada ayat (1)adalah Orang Asing pemegang izin tinggal di Indonesia sesuai dengan ketentuan peraturan perundang-undangan. 
kepemilikan rumah hunian di atas tanah hak pakai atau hak pakai di atas hak milik. ${ }^{3}$

Fokus permasalahan pemilikan rumah tempat tinggal bagi WNA yang menjadi latar belakang pada penulisan artikel ini, yaitu pengaturan jangka waktu penguasaan hak pakai di atas hak milik pada PP terbaru, yang mana,dalam Pasal 4huruf a ayat (2) PP Nomor 103 Tahun 2015mengatur bahwa pemilikan rumah hunian atas hak pakai di atas hak milik, haruslah didasari dengan perjanjian yang dibuat dengan akta Pejabat Pembuat Akta Tanah (selanjutnya disebut dengan PPAT), penguasaannya diberikan selama jangka waktu 30 (tiga puluh) tahun, dan dapat diperpanjang untuk jangka waktu 20 (dua puluh) tahun, serta dapat diperbaharui kembali untuk jangka waktu maksimal 30 (tiga puluh) tahun, sehingga total dari jangka waktu yang diberikan PP Nomor 103 Tahun 2015 tersebut kepada WNA yang menguasai hunian atas hak pakai di atas hak milik yaitu 80 (delapan puluh) tahun. ${ }^{4}$

Dalam penerapannya, pemberian hak pakai di atas tanah hak milik hanya diberikan bagi WNA yang keberadaannya dapat memberikan manfaatterhadapperkembanganpembangunan ekonomi di Indonesia, ${ }^{5}$ sehingga seringkali pemberian terhadap penguasaan hak atas tanah tersebut difungsikan dan dimanfaatkan bagi WNA yang akan melakukan investasi di Indonesia. Bahwa seorang investor yang akan menanamkan modalnya pada suatu bidang usaha tertentu akan selalu memperhatikan faktor-faktor keamanan lingkungan, kepastian hukum, status lahan investasi dan dukungan Pemerintah. ${ }^{6}$ Selain itu, pemberian jangka waktu yang diberikan oleh PP Nomor 103 Tahun 2015 juga memungkinkan bagi WNA untuk tinggal lebih lama dalam menjalankan kegiatan investasinya, hal ini dimungkinkan karena adanya proses perpanjangan dan pembaruan yang diijinkan oleh Pemerintah yang termaktub pada PP Nomor 103 Tahun 2015 tersebut.

Di sisi lain, terdapat peraturan serupa yang mengatur mengenai pemberian jangka waktu hak pakai yang juga dapat dimiliki oleh

3 Pasal 4 huruf a: Rumah tempat tinggal atau hunian yang dapat dimiliki oleh Orang Asing sebagaimana dimaksud dalam Pasal 2 ayat (1) merupakan:

a. Rumah Tunggal di atas tanah:

1. Hak Pakai; atau

2. Hak Pakai di atas Hak Milik yang dikuasai berdasarkan perjanjian pemberian Hak Pakai di atas Hak Milik dengan akta Pejabat Pembuat Akta Tanah.

4 Pasal 7: (1) Rumah Tunggal yang diberikan di atas tanah Hak Pakai sebagaimana dimaksud dalam Pasal 4 huruf a angka 1, diberikan untuk jangka waktu 30 (tiga puluh) tahun;

(2) Hak Pakai sebagaimana dimaksud pada ayat (1) dapat diperpanjang untuk jangka waktu 20 (dua puluh) tahun;

(3) Dalam hal jangka waktu perpanjangan sebagaimana dimaksud pada ayat (2) berakhir, Hak Pakai dapat diperbaharui untuk jangka waktu 30 (tiga puluh) tahun.

5 Maria S.W. Sumardjono, Alternatif Kebijakan Pengaturan Hak Atas Tanah Beserta Bangunan Bagi Warga Negara Asing dan Badan Hukum Asing, (Jakarta: Kompas, 2008), hlm. 11.

6 Bachri, "Survey Faktor-Faktor Non Ekonomi yang Mempengaruhi Iklim Investasi di Sul-Sel, Kajian Ekonomi Regional Sulawesi Selatan”, Triwulan II, 2007, hlm. 33. 
WNA,yaituPeraturan Pemerintah Nomor 40 Tahun 1996 Tentang Hak Guna Usaha, Hak Guna Bangunan dan Hak Pakai atas Tanah (Lembaran Negara Republik Indonesia Nomor 58 Tahun 1996, Tambahan Lembaran Negara Nomor 3643 Tahun 1996), (selanjutnya disebut PP Nomor 40 Tahun 1996), adapun eksistensi PP Nomor 40 Tahun 1996 hingga saat ini masih berlaku dan masih belum diganti oleh peraturan baru. PP Nomor 40 Tahun 1996 menjelaskan bahwa WNA merupakan salah satu subyek hukum yang dapat memiliki tanah di atas hak pakai, sebagaimana yang tertuang didalam Pasal 39 huruf e, yang isinya bahwa yang dapat mempunyai Hak Pakai adalah:

a. Warga Negara Indonesia;

b. Badan hukum yang didirikan menurut hukum Indonesia dan berkedudukan di Indonesia;

c. Departemen, Lembaga Pemerintah Non Departemen, dan Pemerintah Daerah;

d. Badan-badan keagamaan dan sosial;

e. Orang asing yang berkedudukan di Indonesia;

f. Badan hukum asing yang mempunyai perwakilan di Indonesia.

Kewenangan pemilikan atas hak pakai tersebut tentu tidak terlepas dari jangka waktu penguasaannya, PP Nomor 40 Tahun 1996 hanya memberikan jangka waktu pemilikan hak pakai di atas tanah hak milik selama 25 (dua puluh lima) tahun tanpa bisa diperpanjang, namun hanya dapat diperbaharui berdasarkan perjanjian atas kesepakatan antar pemegang hak pakai dengan pemegang hak milik yang dituangkan dalam akta yang dibuat oleh PPAT. $^{7}$

Penerapan hak pakai pada PP Nomor 40 Tahun 1996 diberlakukan secara umum, meskipun demikian, pengaturan hak pakai pada peraturan tersebut akan selalu berkaitan dengan peraturan lain yang menjadikan hak pakai sebagai landasan hak dari suatu kepemilikan obyek tertentu di atas tanah, termasuk hunian. Salah satu perihal terjadinya hak pakai berdasarkan tanahnya yaitu hak pakai atas tanah hak milik. Hak pakai ini terjadi dengan pemberian tanah oleh pemilik tanah dengan akta yang dibuat oleh PPAT, Akta Pejabat Pembuat Akta Tanah tersebut wajib didaftarkan ke Kantor Pertanahan kabupaten atau kota setempat untuk dicatat dalam buku tanah. Bentuk akta PPAT ini dimuat dalam lampiran Peraturan Menteri Agraria atau Kepala Badan Pertanahan Nasional Nomor 3 Tahun $1997,{ }^{8}$ yang kemudian PPAT wajib melaporkan aktanya di setiap bulan kepada BPN berdasarkan

7 Pasal 49 ayat 1 dan 2:

(1) Hak Pakai atas tanah Hak Milik diberikan untuk jangka waktu paling lama dua puluh lima tahun dan tidak dapat diperpanjang.;

(2) Atas kesepakatan antar pemegang Hak Pakai dengan pemegang Hak Milik, Hak Pakai atas tanah Hak Milik dapat diperbaharui dengan pemberian Hak Pakai baru dengan akta yang dibuat oleh Pejabat Pembuat Akta Tanah dan hak tersebut wajib didaftarkan.

8 A.P. Parlindungan, "Beberapa Konsep tentang Hak-hak Atas Tanah”, Majalah CSIS Edisi Tahun XX Nomor 2, Jakarta, 1991, hlm. 117. 
Pasal 26 Peraturan Pemerintah Nomor 37 Tahun 1998 tentang Peraturan Jabatan Pejabat Pembuat Akta Tanah, yang isinya: "PPAT wajib mengirim laporan bulanan mengenai akta yang dibuatnya, yang diambil dari buku daftar akta PPAT sebagaimana dimaksud pada ayat (1) kepada Kepala Kantor Pertanahan dan kantor-kantor lain sesuai ketentuan Undang-Undang atau Peraturan Pemerintah yang berlaku selambat-lambatnya tanggal 10 (sepuluh) bulan berikutnya".

Apabila fokus merujuk pada pengaturan PP Nomor 103 tahun 2015 dan PP Nomor 40 tahun 1996, maka terdapat perbedaan matematis dalam pemberian jangka waktu penguasaan hak pakai di atas hak milik bagi WNA, padahal aturan mengenai jangka waktu tersebut sudah seharusnya menjadi dasar hukum dan memberikan kepastian hukum bagi WNA ketika memiliki rumah hunian atau tempat tinggal atas tanah hak pakai di atas hak milik,terlebih lagi, pemberian jangka waktu hak pakai untuk hunian bagi WNA pada PP Nomor 103 tahun 2015 dapat diperpanjang, sedangkan pemberian jangka waktu hak pakai yang juga dapat diberikan kepada WNA sebagaimana yang dimaksud pada PP Nomor 40 tahun 1996 hanya dapat diperbaharui tanpa boleh diperpanjang.

Mengingat suatu bangunan dan tanah merupakan suatu kesatuan yang tidak dapat dipisahkan, seperti halnya hunian yang dibangun di atas tanah dan satuan rumah susun yang selalu melekat dengan unsur tanahnya, maka sudah seharusnya pemberian jangka waktu hunian bagi WNA yang diatur pada PP Nomor 103 tahun 2015 turut memperhatikan esensi norma pemberian hak pakai yang dimaksud pada PP Nomor 40 tahun 1996, terlebih lagi PP Nomor 40 tahun 1996 merupakan peraturan terdahulu yang masih belum tergantikan oleh peraturan manapun. Sehingga dengan demikian telah terjadi disharmonisasi hukum dari kedua aturan tersebut yang dapat menimbulkan implikasi hukum bagi negara, masyarakat, bahkan pada aturan hukum itu sendiri, sehingga dirasa perlu untuk dilakukan suatu rekonstruksi hukum mengenai pemberian jangka waktu hunian bagi WNA yang berada di Indonesia, agar dapat selaras dengan semangat dan jiwa yang telah dihidupkan oleh peraturan terdahulu, serta meminimalisir terjadinya konflik dan praktik-praktik penyelundupan hukum pada penerapannya dimasa yang akan mendatang.

Dengan demikian berdasarkan uraian tersebut di atas, maka oleh Penulis dilakukan kajian dan penelitian serta dituangkan dalam jurnal yang merupakan hasil dari penelitian tesis, dengan judul "Harmonisasi Pengaturan Pemberian Jangka Waktu Hak Pakai Bagi Warga Negara Asing”.

Berdasarkan latar belakang tersebut di atas maka terdapat permasalahan hukum normatif yang menarik untuk dianalisis, yaitu: Apa implikasi yuridis terhadap disharmonisasi pemberian jangka waktu Hak Pakai bagi Warga Negara Asing dalam konstruksi hukum positif di Indonesia dan Bagaimana rekonstruksipemberian jangka waktu hak 
pakai sebagaihunian bagi Warga Negara Asing dalam konstruksi hukum positif di Indonesia dimasa yang akan mendatang.

Jurnal ini disusun dengan menggunakan metode penelitian yuridis normatif dengan menggunakan metode pendekatan perundangundangan dan pendekatan konseptual, serta menggunakan kajian teori diantaranya, teori hierarki peraturan perundang-undangan, asas-asas pembentukan peraturan perundangundangan, teori kepastian hukum dan konsep hak atas tanah, jurnal ini turut didukung dengan bahan hukum primer berupa Undangundang Dasar Negara Republik Indonesia Tahun 1945, Undang-undang Nomor 5 Tahun 1960 tentang Peraturan Dasar Pokok-Pokok Agraria, Peraturan Pemerintah Nomor 40 Tahun 1996 tentang Hak Guna Usaha, Hak Guna Bangunan dan Hak Pakai atas Tanah, Peraturan Pemerintah Nomor 103 Tahun 2015 tentang Pemilikan Rumah Tempat Tinggal atau Hunian Oleh Orang Asing yang Berkedudukan di Indonesia, Undang-undang Nomor 1 Tahun 2011 tentang Perumahan Dan Kawasan Permukiman, Undang-undang Nomor 20 Tahun 2011 tentang Rumah Susun,Undang-undang Nomor 12 Tahun 2011 tentang Pembentukan Peraturan Perundangundangan dan data sekunder berupa literaturliteratur, hasil-hasil penelitian, makalahmakalah dalam seminar, artikel-artikel yang berkaitan dengan isu hukum yang diangkat dalam jurnal ini.

\section{Pembahasan}

\section{A. Implikasi Yuridis Terhadap} Disharmonisasi Pemberian Jangka Waktu Hak Pakai Bagi Warga Negara Asing Dalam Konstruksi Hukum Positif di Indonesia

Hukum dalam konsep pembaruan masyarakat, maka hukum merupakan alat untuk memelihara ketertiban dalam masyarakat.Pembangunan dan perubahan masyarakat adalah sesuatu yang harus diatur dipelihara dan dilindungi, sehingga dapat menciptakan keselarasan dalam masyarakat. ${ }^{9}$

Menurut Sidharta,dalam melakukan harmonisasi terhadap suatu peraturan perundang-undangan, dapat terjadi beberapa kemungkinan yang menyebabkan terjadinya disharmonisasi, yaitu ${ }^{10}$ :

a. Terjadi inkonsistensi secara vertikal dari segi format peraturan, yakni peraturan yang hierarkinya lebih rendah bertentangan dengan hierarki peraturan yang lebih tinggi, misalnya antara peraturan pemerintah dengan undangundang;

b. Terjadi inkonsistensi secara horisontal dari segi waktu, yakni beberapa peraturan yang secara hierarkis sejajar tetapi yang satu lebih dulu berlaku daripada yang

9 Mochtar Kusumaatmadja, Konsep Hukum Dalam Pembangunan, (Bandung: PPSWN Alumni, 2002), hlm. 1314.

10 Sidharta, dkk, Menuju Harmonisasi System Hukum sebagai Pilar Pengelolaan Wilayah Pesisir Indonesia, (Jakarta: BAPPENAS, 2005), hlm. 14. 
lain;

c. Terjadi inkonsistensi secara horisontal dari segi substansi peraturan, yakni beberapa peraturan yang secara hierarkis sejajar, tetapi substansi peraturan yang satu lebih umum dibandingkan substansi peraturan lainnya;

d. Terjadi inkonsistensi secara horisontal dari segi substansi dalam satu peraturan yang sama, misalnya ketentuan pasal 1 bertentangan dengan ketentuan pasal 15 dari satu undang-undang yang sama; dan

e. Terjadi inkonsistensi antara sumber formal hukum yang berbeda, misalnya antara undang-undang dan putusan hakim atau antara undang-undang dan kebiasaan.

Dengan pendapat Sidharta yang demikian, maka disharmonisasi dapat muncul akibat adanya inkonsistensi baik secara vertikal maupun horisontal.

Menurut L.M. Lapian Gandhi, dalam praktek hukum di Indonesia, terdapat 8 (delapan) faktor penyebab adanya disharmoni itu, yaitu ${ }^{11}$ :

a. Perbedaan antara berbagai undangundang atau peraturan perundangundangan. Selain itu jumlah peraturan yang makin besar menyebabkan kesulitan untuk mengetahui atau mengenal semua peraturan tersebut. Dengan demikian pula ketentuan yang mengatakan bahwa semua orang dianggap mengetahui semua undang-undang yang berlaku niscaya tidak efektif;

b. Pertentangan antara undang-undang dengan peraturan pelaksanaan;

c. Perbedaan antara peraturan perundangundangan dengan kebijkan instansi pemerintah.

d. Perbedaan antara peraturan perundangundangan dengan yuriprudensi dan surat edaran mahkamah agung;

e. Kebijakan-kebijakan instansi pemerintah pusat yang saling bertentangan;

f. Perbedaan antara kebijakan pemerintah pusat dan daerah;

g. Perbedaan antara ketentuan hukum dengan rumusan pengertian tertentu; dan

h. Benturan antara wewenang instansiinstansi pemerintah karena pembagian wewenang yang tidak sistematis dan jelas.

Berdasarkan pendapat kedua ahli sebagaimana tersebut diatas, maka secara umum, adanya disharmonisasi dalam peraturan perundang-undangan disebabkan adannya pengaturan yang tidak bersesuaian, baik secara vertikal maupun horisontal.

Dalam bidang hukum pertanahan di Indonesia, disadari atau tidak, terdapat hubungan yang saling mempengaruhi antara kebijakan hukum di bidang pertanahan dengan kesejahteraan rakyat yang hendak dicapai dengan memformulasikan peraturanperaturan tentang tanah sedemikian rupa, sehingga mencapai kesejahteraan.

Adapun permasalahan yang terjadi saat 
ini, berkaitan dengan peraturan perundangundangan di bidang pertanahan itu sendiri, karena dalam penerapannya tidak semua peraturan perundang-undangan di bidang pertanahan memberikan kepastian hukum bagi masyarakat, dalam hal ini, tidak hanya bagi Warga Negara Indonesia tetapi juga WNA yang tinggal di Indonesia guna mewujudkan kesejahteraan yang dimaksud, diantaranya PP Nomor 103 Tahun 2015.

Diberlakukannya PP Nomor 103 Tahun 2015 sebagai bentuk perubahan dari PP Nomor 41 Tahun 1996, telah mampu memberikan dampak positif untuk perkembangan ekonomi bangsa Indonesia di bidang investasi, karena dalam PP Nomor 103 Tahun 2015 tersebut memungkinkan bagi WNA untuk dapat memiliki hunian di Indonesia. Namun, apabila dianalisis lebih mendalam, selain kelebihan, juga terdapat kelemahan dalam pemberlakuan suatu peraturan pemerintah, khususnya PP Nomor 103 Tahun 2015.Hal ini berkaitan dengan adanya ketentuan yang mengatur tentang pemberian jangka waktu hunian bagi WNA, mengingat perubahan yang paling signifikan dari peraturan yang lama dengan peraturan terbaru ini terdapat pada pemberian jangka waktu hunian bagi WNA tersebut.Meskipun PP Nomor 103 Tahun 2015 esensinya memberikan hak pakai bagi WNA sebagai hunian, namun pada subbab yang akan menjawab rumusan masalah yang pertama pada penelitian ini, dirasa sangat penting bagi Penulis untuk menjabarkan terlebih dahulu mengenai unsur unsur perlekatan hak pakai atas suatu hunian tersebut, karena disitulah ditemukannya disharmonisasi hukum yang disebabkan adanya inkonsistensi secara horisontal dari segi substansi, yaitu pada pengaturan yang memberikan jangka waktu hak pakai di atas tanah hak milik, serta adanya proses perpanjangan dan pembaruan yang tidak bersesuaian, terkait dengan kepemilikan kembali hak pakai tersebut dengan peraturan lain yang masih berlaku hingga saat ini.

Adanya disharmonisasi terkait dengan pengaturan mengenai pemberian jangka waktu sebagaimana yang dimaksud diatas, tentunya secara hukum, dapat menimbulkan ketidakpastian hukum, dalam hal ini, dikarenakan ada 2 (dua) peraturan yang mengatur tentang hak pakai, namun terdapat perbedaan pengaturan mengenai pemberian jangka waktu serta proses perpanjangannya, meskipun di satu sisi, PP Nomor 103 Tahun 2015 merupakan pengaturan yang bersifat khusus, karena mengatur tentang hunian di atas hak pakai. Untuk lebih jelasnya, Penulis akan menguraikan keterkaitan antara hunian diatas tanah hak pakai dengan hak pakai atas tanah itu sendiri.

\section{Hunian di atas tanah hak pakai}

Secara umum, semua hunian berdiri di atas tanah dan melekat dengan tanahnya, yang menurut ketentuan dalam hukum agraria yang berlaku, penguasaan atas tanah telah dibedakan dalam beberapa hak, tergantung dari subyek penguasaannya. Penguasaan tanah oleh WNA yang berkedudukan di Indonesia diatur dalam 
Pasal 42 dan 45 UUPA, yang selanjutnya diatur dalam Peraturan Pemerintah Nomor 40 Tahun 1996, yang mana, dijelaskan bahwa bagi WNA yang berkedudukan di Indonesia hanya dapat diberikan Hak Pakai. ${ }^{12}$

Dalam Pasal 42 UUPA menjelaskan mengenai WNA yang berkedudukan di Indonesia mempunyai hak pakai dan hak sewa atas tanah di Indonesia.Sebagai tindak lanjut ketentuan UUPA tentang jangka waktu hunian yang dapat dimiliki oleh WNA, maka diterbitkan PP Nomor 103 Tahun 2015, dimana dalam peraturan tersebut memuat ketentuan pada Pasal 1 yang menjelaskan mengenai WNA yang berkedudukan di Indonesia dapat memiliki sebuah rumah untuk tempat tinggal atau hunian dengan hak atas tanah tertentu, dimana WNA tersebut merupakan pihak yang telah memenuhi syarat dan ketentuan dalam peraturan perundang-undangan yang berlaku, sehingga oleh negara diperkenankan untuk memiliki sebuah rumah tempat tinggal yang berdiri sendiri (selanjutnya disebut hunian) atau satuan rumah susun yang dibangun di atas tanah Hak Pakai. ${ }^{13}$ Pengertian hunian itu sendiri telah diatur sebagaimana yang tertuang dalam Pasal 1 ayat (7) Undang-undang Nomor 1 Tahun 2011 tentang Perumahan dan Kwasan Permukiman yaitu bangunan gedung yang berfungsi sebagai tempat tinggal yang layak huni, sarana pembinaan keluarga, cerminan harkat dan martabat penghuninya, serta aset bagi pemiliknya.
Berdasarkan PP Nomor 103 Tahun 2015, menyatakan bahwa salah satu hak penguasaan atas tanah yang dapat dijadikan suatu obyek hunian bagi WNA hanyalah hak pakai atau hak pakai di atas hak milik. Dikarenakan PP Nomor 103 tahun 2015 menyebutkan bahwa hak pakai merupakan salah satu alas hak yang dapat dimiliki oleh WNA, maka khusus pada pengaturan hak pakai yang terdapat pada peraturan tersebut sudah seharusnya tidak mengabaikan pengaturan hak pakai yang telah diatur sebelumnya pada PP Nomor 40 Tahun 1996, karena suatu obyek hunian, termasuk hunian yang dimiliki oleh WNA akan selalu melekat dengan kedudukan tanahnya. Analogi sederhana dari suatu konsep hunian tidak terlepas dari unsur hak atas tanahnya adalah tidak adanya sutu hunian yang mengambang atau melayang dari tanahnya.

Sebagai contoh konkrit untuk memperkuat argumentasi bahwa suatu hunian tidak dapat terpisahkan dengan unsur tanahnya adalah dengan adanya rumah susun, sebagaimana yang diatur pada Pasal 7 Undang-undang Nomor 20 Tahun 2011 tentang Rumah Susun (selanjutnya disebut UURS), yang mengatur bahwa rumah susun hanya dapat dibangun di atas tanah Hak Milik, Hak Guna Bangunan, Hak Pakai atas tanah Negara atau tanah Hak Pengelolaan. Selanjutnya dalam Pasal 8 ayat (1) UURS mengatur bahwa satuan Rumah Susun dimiliki perseorangan atau badan hukum yang memenuhi syarat sebagai

12 Maria Sumardjono, Pengaturan Hak Atas Tanah Beserta Bangunan, (Jakarta: Buku Kompas, 2007), hlm. 7.

13 Ibid., hlm. 8 . 
pemegang hak atas tanah. Dalam Pasal 8 ayat (2) yang sama ditegaskan pula bahwa Hak Milik Satuan Rumah Susun meliputi juga hak atas bagian bersama, benda bersama dan tanah bersama yang kesemuanya merupakan satu kesatuan yang tidak terpisahkan dengan satuan yang bersangkutan, dengan kata lain, UURS ini menganut asas pelekatan vertikal. ${ }^{14}$

Berdasarkan uraian diatas, maka telah menunjukkan bahwa hunian, baik berupa rumah tinggal maupun rumah susun melekat atau tidak dapat dipisahkan dengan tanahnya.

\section{Inkonsistensi \\ pengaturan mengenai pemberian jangka waktu hak pakai atas hunian bagi WNA}

Pemberian jangka waktu hunian bagi WNA merupakan suatu hal yang sangat penting. Urgensi tersebut mengacu pada seberapa lama WNA dapat memiliki hunian di atas hak pakai di Indonesia, hal tersebut berkaitan juga dengan perjanjian yang akan dibuat oleh WNA dengan pemegang hak milik atas tanah yang akan digunakan sebagai hunian bagi WNA (mengingat hak pakai di atas tanah hak milik), yang kemudian perjanjian tersebut harus dibuat dengan akta yang dibuat oleh PPAT dan wajib dicatat dalam buku tanah serta sertifikat hak atas tanah yang bersangkutan, sehingga, apabila pemberian jangka waktu tersebut telah jelas dan berjalan sesuai dengan prosedur yang seharusnya, maka dengan demikian hal tersebut sudah seharusnya dapat memberikan kepastian hukum bagi WNA yang memiliki hunian di Indonesia.

Pemberlakuan PP Nomor 103 Tahun 2015, sesungguhnya tidak terlalu mendapat perhatian yang mendalam dari masyarakat. PP Nomor 103 Tahun 2015 tersebut kemudian menjadi perhatian,karena yang menjadi titik perubahan adalah jangka waktu hak pakai sebagaimana yang temuat di dalam Pasal 7, yang isinya:

“(1) Rumah Tinggal yang diberikan di atas tanah Hak Pakai sebagaimana dimaksud dalam Pasal 4 huruf a angka 1, diberikan untuk jangka waktu 30 (tiga puluh) tahun;

(2) Hak Pakai sebagaimana dimaksud pada ayat (1) dapat diperpanjang untuk jangka waktu 20 (dua puluh) tahun;

(3) Dalam hal jangka waktu perpanjangan sebagaimana dimaksud pada ayat (2) berakhir, Hak Pakai dapat diperbaharui untuk jangka waktu 30 (tiga puluh) tahun."

sehingga dari ketentuan sebagaimana tersebut diatas, maka memungkinkan bagi WNA untuk memiliki Hunian diatas Hak Pakai bagi WNA, untuk jangka waktu 80 (delapan puluh) tahun dengan tambahan proses perpanjangan dan pembaharuan atas Hak Pakai yang dimaksud.

Adapun yang menjadi latar belakang dari

14 Asas Pelekatan Vertikal adalah pelekatan secara tegak lurus yang melekatkan semua benda yang ada di atas maupun di dalam tanah sebagai benda pokoknya.Asas ini dapat ditemukan dalam Pasal 571 KUHPerdata yang isinya, "Hak Milik atas sebidang tanah mengandung di dalamnya, kemilikan atas segala apa yang ada di atasnya dan di dalam tanah". 
pemberian jangka waktu hak pakai selama 80 (delapan puluh) tahun tersebut oleh Pemerintah tentu didasari oleh pertimbangan faktor ekonomi, karena berlakunya PP Nomor 103 Tahun 2015 ini sangat mendukung dan mengembangkan prospek industri di bidang properti di Indonesia, namun dengan adanya disharmonisasi pengaturan sebagaimana yang telah Penulis uraikan sebelumnya, tentunya dapat menimbulkan ketidakpastian hukum bagi WNA terutama pada saat akan melakukan perpanjangan maupun pembaharuan bilamana jangka waktu yang diberikan telah berakhir.

Tujuan Pemerintah dalam mengejar pertumbuhan ekonomi sepatutnya harus didukung karena hal tersebut semata-mata demi kesejahteraan rakyat Indonesia. Namun disisi lain, semangat pemerintah dalam meningkatkan pertumbuhan ekonomi jangan sampai melanggar tatanan serta bangunan hukum yang telah terbangun, bahkan mengesampingkan kepentingan rakyat Indonesia untuk bisa memiliki properti di bidang pertanahan dalam situasi yang sangat berat ditengah persaingan dengan WNA.

Sebagaimana yang telah diuraikan pada sub-bab pembahasan sebelumnya, bahwa sebenarnya, jangka waktu Hak Pakai di atas tanah hak milik telah lama diatur dalam Pasal 49 PP Nomor 40 Tahun 1996 yang isinya:

“(1) Hak Pakai atas tanah Hak Milik diberikan untuk jangka waktu paling lama 25 (dua puluh lima) tahun dan tidak dapat diperpanjang;

(2) Atas kesepakatan antar pemegang Hak Pakai dengan pemegang Hak Milik,
Hak Pakai atas tanah Hak Milik dapat diperbaharui dengan pemberian Hak Pakai baru dengan akta yang dibuat oleh Pejabat Pembuat Akta Tanah dan hak tersebut wajib didaftarkan."

yang berarti hak pakai bagi WNA hanya terbatas sampai jangka waktu 25 (dua puluh lima) tahun, dan apabila telah berakhir, maka WNA tersebut harus melakukan proses pembaharuan saja, dengan demikian, menunjukkan bahwa pemberian hak pakai bagi WNA sangat ketat karena melalui proses pengkajian secara administrasi untuk menilai apakah WNA memenuhi ketentuan perundang-undangan untuk menerima Hak Pakai di Indonesia.

Berdasarkan 2 (dua) ketentuan peraturan perundang-undangan yang telah Penulis uraikan diatas, apabila ditinjau dari segi penerapannya, maka terdapat inkonsistensi antar peraturan perundang-undangan mengenai pemberian jangka waktu hak pakai di atas tanah hak milik yang diatur dalam Pasal 7 PP Nomor 103 Tahun 2015 dengan Pasal 49 PP Nomor 40 Tahun 1996, sehingga telah menimbulkan disharmonisasi secara hukum dalam peraturan perundang-undangan.

Sebagai bentuk perbandingan dari segi substansi hukum, inkonsistensi pemberian jangka waktu hunian bagi WNA yang diatur pada Pasal 7 PP Nomor 103 Tahun 2015 terlihat lebih jelas,bilamana dibandingkan dengan peraturan yang pernah diberlakukan sebelumnyadan saat ini sudah dicabut, yaitu PP Nomor 41 Tahun 1996, (sebagaimana diubah menjadi PP Nomor 103 Tahun 2015), 
ternyata lebih konsisten atau seirama dengan PP Nomor 40 Tahun 1996, konsistensi tersebut dapat dilihat dalam Pasal 5 PP Nomor 41 Tahun 1996 yang isinya:

“(1) Perjanjian sebagaimana dimaksud dalam Pasal 2 angka 1 dibuat untuk jangka waktu yang disepakati, tetapi tidak lebih lama dari dua puluh lima tahun.

(2) Jangkawaktusebagaimana dimaksud dalam ayat (1) dapat diperbaharui untuk jangka waktu yang tidak lebih lama dari dua puluh lima tahun, atas dasar kesepakatan yang dituangkan dalam perjanjian yang baru, sepanjang orang asing tersebut masih berkedudukan di Indonesia."

Dalam ketentuan diatas, dapat dilihat adanyakesesuaian pemberian jangka waktu hak pakai bagi WNA antara PP nomor 40 tahun 1996 dengan PP Nomor 41 Tahun 1996, yang mana, keduanya sama-sama mengatur bahwa pemberian jangka waktu hak pakai bagi WNA adalah selama 25 (dua puluh lima) tahun, dengan demikian pula memperlihatkan adanya konsistensi hukum yang baik dan keseimbangan antar peraturan perundang-undangan yang satu dengan yang lainnya, karena dengan peraturan hukum yang konsisten maka akan melahirkan suatu keharmonisan hukum, hal tersebut berlaku juga sebaliknya.

Meskipun keberlakukan PP Nomor 103 Tahun 2015 yang merupakan perubahan dari PP Nomor 41 Tahun 1996 merupakan peraturan yang lebih khusus yang mengatur Hunian di atas Hak Pakai bagi WNA, yang didalamnya memuat ketentuan mengenai pemberian jangka waktu hak pakai atas suatu huniannya, sehingga apabila terjadi inkonsistensi dalam peraturan perundangundangan maka dapat diselesaikan dengan menerapkan asas lex specialis derogat legi generali, akan tetapi perlu diingat kembali bahwa yang terjadi pada kedua peraturan ini bukanlah kontradiksi, melainkan adanya ketidaksesuaian yang menyebabkan munculnya disharmonisasi hukum yang kajian penyelesaiannya tidak cukup diselesaikan dengan menerapkan asas lex specialis derogat legi generali. Disharmonisasi tersebut muncul karena pada dasarnya terdapat hubungan antara pengaturan mengenai hunian di atas tanah hak pakai dengan pengaturan mengenai hak pakai atas tanah bagi WNA, dalam hal ini, hak pakai merupakan salah satu hak penguasaan terhadap tanah yang penguasaannya dibatasi dengan pemberian jangka waktunya sebagaimana diatur pada Pasal 7 PP Nomor 40 Tahun 1996, yang dalam pengaturannya, hubungan tersebut tidak terjalin dengan harmonis antara peraturan satu dengan peraturan lainnya, karenanya perlu dilakukan reformulasi terhadap peraturan mengenai pemberian jangka waktu hak pakai bagi WNA.

\section{Dualisme pengaturan mengenai perpanjangan dan pembaruan hak pakai bagi warga negara asing}

Melihat perkembangan pengaturan tentang Hak Pakai dengan ditempatkannya Hak Pakai sebagai alas hak dari suatu hunian bagi WNA mencerminkan bahwa Hak Pakai dipandang sangat bermanfaat untuk 
meningkatkan kesejahteraan masyarakat, terutama bagi masyarakat kecil serta pihak yang memberikan Hak Pakai bagi WNA berdasarkan perjanjian akan menarik minat pemodal asing untuk menanamkan modalnya di Indonesia yang akan bermanfaat bagi pembangunan di Indonesia.

Berkaitan dengan hak asing yang dapat menguasai hak pakai ini, menurut Tampil Anshari Siregar perlu diingat bahwa hak pakai atas tanah yang diberikan kepada WNA harus benar-benar memiliki status kedudukan yang sah (termasuk dokumen yang diperlukan) di Indonesia dan/atau badan hukum asing yang mempunyai perwakilan di Indonesia dalam pengertian bahwa aktivitas WNA dan badan hukum asing dimaksud harus benar-benar memberi manfaat bagi pembangunan nasional Indonesia. ${ }^{15}$ Oleh karena itu, diperlukan adanya pengaturan yang harmonis serta dukungan dari aparat penegak hukum dalam menegakkan peraturan hukum, sehingga tujuan dari dibentuknya PP Nomor 103 Tahun 2015 dapat diwujudkan dengan optimal.

Dalam ketentuan Pasal 4 huruf a ayat (2) PP Nomor 103 Tahun 2015 ini, memberikan hak kepada WNA untuk melakukan perpanjangan atas hak pakai yang diberikan kepadanya untuk jangka waktu 20 (dua puluh) tahun dan dapat diperbaharui kembali untuk jangka waktu maksimal 30 (tiga puluh) tahun, sehingga total jangka waktu yang diberikan kepada WNA untuk menguasai hunian atas hak pakai adalah 80 (delapan puluh) tahun. Total jangka waktu tersebut, lebih lama dibandingkan dengan total jangka waktu yang diatur dalam PP Nomor 40 Tahun 1996. Pemberian jangka waktu sebagaimana tersebut di atas, tentu telah ditetapkan dengan berbagai pertimbangan, sehingga di kemudian hari tidak menimbulkan dampak negatif dalam pelaksanaannya.Namun, apabila dilakukan analisis secara lebih mendalam, terdapat kelonggaran secara administrasi, terkait dengan ketentuan dapat dilakukannya perpanjangan atas hak pakai bagi WNA.

Menurut Pasal 1 ayat (9) Peraturan Menteri Agraria / Kepala Badan Pertanahan Nasional Nomor 9 Tahun 1999 tentang Tata Cara Pemberian dan Pembatalan Hak Atas Tanah Negara dan Hak Pengelolaan, memberikan definisi perpanjangan hak, yaitu perpanjangan hak adalah penambahan jangka waktu berlakunya sesuatu hak atas tanah tanpa mengubah syarat-syarat dalam pemberian hak tersebut, yang permohonannya dapat diajukan sebelum jangka waktu berlakunya hak atas tanah yang bersangkutan berakhir. Sedangkan dalam ayat (10), mendefinisikan Pembaruan hak, yaitu pemberian hak atas tanah yang sama kepada pemegang hak yang sama yang dapat diajukan setelah jangka waktu berlakuknya hak yang bersangkutan berakhir.

Berdasarkan kedua pengertian di atas, jelas memberikan penjelasan yang berbeda antara perpanjangan hak dengan pembaruan 
hak. Dalam hal ini, perpanjangan hak, hanya memberikan tambahan jangka waktu kepada pemegang hunian atas hak pakai tanpa diikuti dengan pembaruan syarat-syarat, padahal dimungkinkan setelah melebihi jangka waktu 30 (tiga puluh) tahun sejak dikuasainya hunian berdasarkan hak pakai telah terdapat perubahan, diantaranya,

a. segi subyek, misalnya pemegang hak pakai meninggal dunia sehingga terjadi waris;

b. segi administrasi, berkaitan dengan ijin WNA untuk tinggal di Indonesia;

c. ketentuan hukum maupun persyaratan yang ditentukan oleh undang-undang, misalnyaterdapatperubahanbuktimaupun syarat karena diberlakukannya Peraturan Pemerintah baru maupun peraturan yang sejajar lainnya,yang bila hal tersebut disertakan dalam permohonan maupun dalam perjanjian dengan pemegang hak milik, dikhawatirkan akan menimbulkan permasalahan hukum maupun kerugian baik bagi pemegang hak milik maupun bagi negara dikemudian hari, mengingat waktu perpanjangan yang diberikan cukuplah lama, yaitu 20 (dua puluh) tahun. Sedangkan dalam hal pembaruan hak, pemegang hunian atas hak pakai, mengajukan permohonan baru kepada pejabat yang berwenang untuk itu, dengan menyertakan bukti-bukti baru, sehingga baik secara hukum maupun secara administrasi dapat diperoleh kebaruan dari bukti-bukti yang ada, sebagai syarat untuk mengajukan permohonan maupun pendaftaran hak.

Berdasarkan uraian tentang adanya disharmonisasi antar Peraturan Pemerintah yang mengatur mengenai hak pakai, yang mana terdapat inkonsistensi pengaturan mengenai pemberian jangka waktu hak pakai bagi WNA maupun dualisme pengaturan mengenai perpanjangan hak dan pembaruan hak tentunya bertentangan dengan tujuan hukum maupun teori hukum yang ada, dalam hal ini, dengan adanya inkonsistensi dan dualisme yang sebagaimana telah dijelaskan di atas, maka hal tersebut menimbulkan ketidakpastian hukum bagi WNA dan bertentangan dengan asas-asas pembentukan peraturan perundang-undangan, yang salah satunya menganut tentang asas kesesuaian antara jenis dan materi muatan yang menjadi hal penting dalam pembentukan suatu peraturan perundang-undangan sebagaimana diatur dalam Pasal 5 Undang-undang Nomor 12 Tahun 2011 tentang Pembentukan Peraturan Perundang-undangan, yang isinya:

"Dalam membentuk peraturan perundang-undangan harus dilakukan berdasarkan pada asas pembentukan peraturan perundang-undangan yang baik, yang meliputi :

a. Kejelasan tujuan;

b. Kelembagaan atau pejabat pembentuk yang tepat;

c. Kesesuaian antara jenis, hierarki dan materi muatan;

d. Dapat dilaksanakan;

e. Kedayagunaan dan kehasilgunaan;

f. Kejelasan rumusan dan keterbukaan."

Melihat kondisi yang demikian, sehingga 
diperlukan adanya suatu harmonisasi antara PP Nomor 40 Tahun 1996 dengan PP Nomor 103 Tahun 2015, khususnya terhadap pengaturan mengenai pemberian jangka waktu hak pakai bagi WNA.

Adapun menurut Kamus Besar Bahasa Indonesia, harmonisasi berasal dari kata harmoni yang artinya, keselarasan, keserasian. Harmonisasi dalam Bahasa Inggris disebut harmonize, dalam bahasa Francis disebut dengan harmonie, dan dalam bahasa yunani disebut harmonia. ${ }^{16}$

Menurut L.M Gandhibahwa harmonisasi dalam hukum adalah mencakup penyesuaian peraturan perundang-undangan, keputusan pemerintah, keputusan hakim, sistem hukum dan asas-asas hukum dengan tujuan peningkatan kesatuan hukum, kepastian hukum, keadilan (justice, gerechtigheid) dan kesebandingan (equit, billijkeid), kegunaan dan kejelasan hukum, tanpa mengaburkan dan mengorbankan pluralisme hukum kalau memang dibutuhkan, sedangkan menurut Badan Pembinaan Hukum Nasional dalam buku yang disusun oleh Moh. Hasan Wargakusumah, dkk, bahwa harmonisasi hukum adalah kegiatan ilmiah untuk menuju proses pengharmonisasian tertulis yang mengacu baik pada nilai-nilai filosofis, sosiologis, ekonomis maupun yuridis.

Harmonisasi dalam pembentukan undang-undang mempunyai fungsi yang sangat penting, agar dalam penerapannya dikemudian hari tidak menimbulkan tumpang tindih (overlap) kewenangan antara undangundang yang satu dengan undang-undang lainnya. Dalam hal ini, harmonisasi dalam pembentukan undang-undang bertujuan untuk menyelaraskan aturan-aturan yang terdapat dalam materi muatan undang-undang, sehinggamenghindari terjadinya tumpang tindih antara materi undang-undang yang satu dengan yang lainnya yang dapat menibulkan kekacauan dalam penegakan hukumnya (law enforcement) di kemudian hari.Selain itu, menghindari terjadi "dualisme" hukum, yang dapat mengganggu prosedur penegakan hukum itu sendiri.

Wacipto Setiadi berpendapat bahwa, untuk memenuhi ketentuan Pasal 18 ayat (2) Undang-undang tentang Pembentukan Peraturan Perundang-Undangan, paling tidak ada tiga alasan atau fungsi harmonisasi hukum, yaitu ${ }^{17}$ :

a. Pengharmonisasian dilakukan untuk menjaga keselarasan, kemantapan dan kebulatan konsepsi peraturan perundangundangan sebagai sistem dengan tujuan peraturan tersebut dapat berfungsi secara efektif;

b. Harmonisasi hukum dilakukan sebagai upaya prefentif, dalam rangka pencegahan diajukannya permohonan judicial reviewperaturan perundangundangan kepada kekuasaan kehakiman yang berkompeten;

c. Menjamin proses pembentukan peraturan

16 Suhartono, "Harmonisasi Peraturan Perundang-undangan dalam Pelaksanaan Anggaran Belanja Negara", Disertasi Ilmu Hukum, (Jakarta: Fakultas Hukum Universitas Indonesia, 2011), Tidak Dipublikasikan, hlm. 94.

17 Wacipto Setiadi, "Proses Pengharmonisasian sebagai Upaya Untuk Memperbaiki Kualitas Peraturan Perundangundangan”, Jurnal Legislatif Indonesia, Vol. 4, (Juni 2007): 48. 
perundang-undangan dilakukan secara taat asas hukum, demi kepentingan dan kepastian hukum.

Berdasarkan pendapat yang dikemukakan oleh para ahli sebagaimana yang telah diuraikan diatas, menunjukkan bahwa harmonisasi dalam pembentukan peraturan perundang-undangan sangat penting, yaitu untuk menyelaraskan ketentuan pasal per pasal dalam satu undang-undang maupun ketentuan antar undang-undang, sehingga tidak terjadi tumpang tindih pengaturan maupun adanya aturan hukum yang saling bertentangan, yang dapat menimbulkan masalah ketika diterapkan dalam rangka untuk penegakan hukum, dan diharapkan peraturan tersebut dapat mewujudkan kepastian hukum serta asas-asas dalam pembentukan peraturan perundang-undangan.

\section{B. Rekonstruksi Pemberian Jangka Waktu Hak Pakai Sebagai Hunian Bagi Warga Negara Asing Dalam Konstruksi Hukum Positif Di Indonesia Dimasa Yang Akan Mendatang}

1. Pemberian jangka waktu hak pakai sebagai hunian bagi warga negara asing

Berdasarkan pada bagian latar belakang serta pembahasan atas permasalahan yang ada, maka terdapat urgensi untuk dilakukan harmonisasi terhadap ketentuan dalam PP Nomor 40 Tahun 1996 dengan PP Nomor 103 Tahun 2015, khususnya terhadap pengaturan mengenai pemberian jangka waktu yang merupakan bagian penting dalam peraturan ini demi terwujudnya kepastian hukum tentang seberapa lama WNA berhak untuk memiliki hunian di Indonesia. Bilamana pemberian jangka waktu tersebut tidak jelas, kabur dan/ atau tidak berkesesuaian dengan peraturan yang telah ada sebelumnya dan hingga saat ini masih berlaku, maka kepastian hukum tersebut tidak akan tercapai.

Untuk benar-benar menjamin kepastian hukum, selain syarat-syarat formal, suatu peraturan perundang-undangan juga harus memenuhi syarat-syarat lain, yaitu:

a. Jelas dalam perumusannya (unambiguous);

b. Konsisten dalam perumusannya baik secara intern maupun ekstern.

Konsisten secara intern mengandung makna bahwa dalam peraturan perundang-undangan yang sama harus terpelihara hubungan sietematik antara kaidah-kaidahnya, kebakuan susunan dan bahasa. Konsisten secara ekstern, adalah adanya hubungan "harmonisasi" antara berbagai peraturan perundang-undangan; c. Penggunaan bahasa yang tepat dan mudah dimengerti.

Bahasa peraturan perundang-undangan harus menggunakan bahasa yang umum dalam masyarakat,namun tidak berarti bahasa hukum tidak penting. Bahasa hukum, baik dalam arti struktur, peristilahan, atau cara penulisan tertentu harus dipergunakan secara "ajeg" karena 
merupakan bagian dan upaya menjamin kepastian hukum.

Dengan demikian, selain unsur formal dalam pembentukan peraturan perundangundangan, ketiga unsur di atas harus turut serta dijadikan landasan pemikiran dalam rekonstruksi peraturan perundang-undangan yang menjadi obyek dari pembahasan ini, adapun rekonstruksi yang menurut pendapat penulis harus dilakukan untuk menghindari konflik hukum dan mencapai kepastian hukum dalam pengaturan pemberian jangka waktu hak pakai sebagai hunian bagi WNA, yaitu melakukan perbaikan terhadap Pasal 7 PP Nomor 103 Tahun 2015 yang memberikan jangka waktu hunian atas tanah hak pakai di atas tanah hak milik selama 80 (delapan puluh tahun) menjadi 25 (dua puluh lima) tahun. Adapun beberapa pertimbangan untuk dilakukan perbaikan terhadap Pasal 7 PP Nomor 103 Tahun 2015 tersebut, antara lain :

a. Menyelaraskan esensi norma yang terdapat pada PP Nomor 40 Tahun 1996 sebagai peraturan dasar yang mengatur pemberian jangka waktu hak pakai bagi WNA, yaitu selama 25 (dua puluh lima) tahun, demi menyatukan cita hukum yang dibentuk oleh pembentuk peraturan perundang-undangan terdahulu;

b. Menghindari ambiguitas yang terjadi pada penerapannya, khususnya dalam praktik yang dilakukan oleh PPAT selaku pejabat yang berwenang untuk membuat akta perjanjian antara pemegang hak milik atas tanah dengan penerima hak pakai (WNA) yang akan dijadikan hunian;

c. Menghindari peluang gugatan yang dilayangkan oleh subyek hukum yang tidak beritikad baik, dengan menjadikan disharmoni pemberian jangka waktu hak pakai tersebut sebagai dasar gugatan.

\section{Pengaturan proses perpanjangan dan pembaruan hak pakai sebagai hunian bagi warga negara asing}

Proses perpanjangan dan pembaruan tidak bisa dikatakan sebagai proses yang sederhana dan sepele, mengingat antara proses pepanjangan dengan pembaruan memiliki implikasi hukum yang berbeda. Maka menurut hemat penulis perlu kiranya pengaturan terhadap proses perpanjangan dan pembaruan hak pakai yang diberikan bagi WNA sebagai hunian diatur secara seirama, artinya tidak ada dualisme yang muncul pada pengaturan proses perpanjangan dan pembaruan tersebut.

Adapun pendapat penulis terhadap pengaturan yang seharusnya mengatur mengenai proses perpanjangan dan pembaruan dalam rekonstruksi ini yaitu, menghapuskan proses perpanjangan pada pengaturan pemberian jangka waktu hak pakai untuk hunian bagi WNA dalam setiap pasal yang ada. Adanya proses perpanjangan bukanlah suatu hal yang buruk, akan tetapi mengingat proses perpanjangan dan pembaruan tersebut diberikan kepada WNA, maka akan lebih baik bilamana didalam peraturan tersebut hanya ada proses pembaruan, tanpa adanya proses perpanjangan, dengan alasan dan 
pertimbangan sebagai berikut:

a. Proses perpanjangan sangat rentan untuk dijadikan celah hukum yang dimanfaatkan oleh WNA untuk dapat "lolos" dari seleksi kelayakan untuk tetap berhuni di Indonesia;

b. Dengan hanya menekankan pada proses pembaruan, maka proses tersebut akan membantu pemerintah untuk selektif dalam menentukan apakah WNA tersebut tetap layak berhuni di Indonesia atau tidak. Dengan proses pembaruan, maka diharuskan adanya pengajuan atau permohonan ulang dengan menyertakan bukti yang sah dan valid, termasuk pembaruan perjanjian dengan pemegang hak milik atas tanah yang dinuat oleh PPAT.

Dengan demikian, sebagai bentuk konkrit yang dapat diberikan oleh penulis dari hasil rekonstruksi pengaturan pemberian jangka waktu hunian atas hak pakai di atas hak milik bagi WNA, maka berdasarkan beberapa pertimbangan dan alasan yang telah diuraikan tersebut di atas, dapat direkonstruksi sebagai berikut:

\section{Pasal 7 \\ "Jangka Waktu"}

(1) Rumah Tunggal di atas tanah Hak Pakai di atas Hak Milik yang dikuasai berdasarkan perjanjian sebagaimana dimaksud dalam Pasal $\mathrm{X}$ huruf $\mathrm{X}$ angka $\mathrm{X}$ diberikan Hak Pakai untuk jangka waktu yang disepakati tidak lebih lama dari 25 (dua puluh lima) tahun;

(2) Dalam hal jangka waktu sebagaimana dimaksud pada ayat (1) berakhir, Hak
Pakai hanya dapat diperbaharui untuk jangka waktu paling lama 25 (dua puluhlima) tahun sesuai kesepakatan dengan pemegang hak atas tanah.

Hasil rekonstruksi di atas terdapat beberapa perubahan dan/atau penyesuaian pengaturan mengenai pemberian jangka waktu hak pakai bagi WNA sebagai hunian serta pengaturan diberlakukannya prosedur pembaruan tanpa mengenal kembali prosedur perpanjangan dalam Pasal 7 PP Nomor 103 Tahun 2015.

Dengan melakukan rekonstruksi terhadap pengaturan pemberian jangka waktu hak pakai sebagai hunian bagi WNA, maka diharapkan akan dapat memberikan kepastian hukum mengenai berapa lama WNA dapat memiliki hunian di Indonesia tanpa terjadi suatu inkonsistensi dengan peraturan yang lain, serta terhindar dari dualisme pemberian proses perpanjangan dan pembaruan hak pakai yang diperuntukkan bagi WNA. Dalam proses rekonstruksi tersebut harus tetap pada jalur hierarki peraturan perundang-undangan di Indonesia sebagai Peraturan Pemerintah, meskipun tidak dapat dipungkiri bilamana pengaturan tersebut dapat menjadi suatu Undang-undang yang kedudukannya lebih tinggi dari Peraturan Pemerintah. Selain itu, rekonstruksi pengaturan tersebut juga harus taat pada asas peraturan perundang-undangan dengan memegang prinsip dasar yang diatur dalam Undang-undang Nomor 12 Tahun 2011 tentang Pembentukan Peraturan Perundangundangan.

Penulis pun menyadari bahwa untuk melakukan rekonstruksi suatu peraturan 
perundang-undangan membutuhkan peran Pemerintah, khususnya lembaga legislatif untuk tetap memberikan produk hukum yang progresif agar dapat mengikuti tuntutan zaman serta tidak mengabaikan kemanfaatan yang diperuntukkan sebesar-besarnya bagi masyarakat.

\section{Peran serta masyarakat dalam optimalisasi pengaturan peratanahan yang diperuntukkan bagi Warga Negara Asing}

Hal lain yang dapat menjadi salah satu alasan perlunya dilakukan rekonstruksi terhadap ketentuan Pasal 7 PP Nomor 103 Tahun 2015, adalah mengoptimalkan fungsi dari hak pakai atas tanah sebagai landasan hukum bagi WNA untuk memiliki suatu hunian diera yang berkembang begitu pesat, salah satunya pertumbuhan ekonomi.Dalam hal ini, menurut Maria S. W.Sumardjono, dalam menghadapi tantangan era yang berkembang begitu pesat ini paling tidak, dapat dicatat dua macam reaksi yang sering muncul, yakni, reaksi yang didasarkan pada pendekatan yang legalistik, yang dengan sikap konserpatif sulit menerima perkembangan-perkembangan baru dan cenderung menolaknya dengan alasan bahwa hal tersebut tidak ditunjuk secara eksplisit dalam suatu undang-undang. Sebaliknya, reaksi lain yang berpangkal pada pendekatan fungsional cenderung bersikap sangat akomodatif terhadap perkembangan- perkembangan baru dengan mengatasnamakan kemanfaatan hal-hal tersebut dan bila perlu mengusulkan untuk merubah undangundangnya.

Berdasarkan pendapat tersebut, maka perlu dilakukan perubahan terhadap undang-undang, sehingga dapat sejalan dengan dinamika perubahan yang terjadi di masyarakat, yang tentunya dilakukan dengan tidak mengabaikan aspirasi masyarakat, karena kebiasaan dalam masyarakat merupakan sumber hukum. ${ }^{18}$ Dengan demikian, perubahan yang akan dilakukan haruslah perubahan yang teratur, bukan suatu perubahan yang justru akan menimbulkan ketidakteraturan.

Perlunya melakukan perubahan dan pembangunan hukum guna menyesuaikan dengan dinamika masyarakat yang terus berkembang, menurutMochtar Kusumaatmadja terdapat ukuran dalam melakukan perkembangan hukum mengenai pemilihan bidang hukum mana yang hendak dikembangkan, antara lain ${ }^{19}$ :

a. Ukuran keperluan yang mendesak (urgen need);

b. Feasibility; bidang hukum yang terlalu banyak mengandung halangan ditangguhkan dan dipilih bidang-bidang yang tidak ada kompilasi-kompilasi kultural, keamanan dan sosiologis;

c. Perubahan yang pokok (fundamental change); di sini perubahan (melalui 
peraturan

perundang-undangan)

diperlukan karena pertimbangan politis, ekonomi, dan/atau kesejahteraan sosial.

Mengingat salah satu tujuan utama dalam pembentukan peraturan perundang undangan adalah untuk mewujudkan tujuan hukum, maka penulis berpendapat bahwa dalam melakukan optimalisasi pengaturan pertanahan yang diperuntukkan bagi WNA dimasa yang akan datang, perlu kiranya memberikan kesempatan bagi masyarakat untuk turut berpatisipasi dalam proses pembentukan peraturan perundang-undangan tersebut, khususnya berkaitan dengan tanah, karena segala hal yang berhubungan dengan tanah memiliki tingkat sensitifitas yang sangat tinggi di mayarakat.Penyediaan ruang publik atau adanya partisipasi masyarakat merupakan tuntutan yang mutlak dalam sebuah negara demokrasi seperti Indonesia. Partisipasi masyarakat dalam setiap tahapan tersebut harus benar-benar dilindungi oleh negara dalam pelaksanannya, agar prinsipprinsip demokrasi tidak terlanggar oleh penguasa. Selain itu, partisipasi masyarakat juga berhubungan dengan keterbukaan informasi yang juga dijamin pelaksanaannya oleh Undang-Undang Nomor 14 Tahun 2008 tentang Keterbukaan Informasi Publik sebagaimana diatur dalam Pasal 8, yang menjelaskan tujuan dari keterbukaan informasi publik, antara lain:

a. Menjamin hak warga negara untuk mengetahuirencana pembuatan kebijakan publik, program kebijakan publik, dan proses pengambilan keputusan publik, serta alasan pengambilan suatu keputusan publik;

b. Mendorong partisipasi masyarakat dalam proses pengambilan kebijakan publik; dan

c. Meningkatkan peran aktif masyarakat dalam pengambilan kebijakan publik.

Berdasarkan tujuan diberlakukannya peraturan mengenai keterbukaan informasi bagi publik, dapat dikatakan bahwa UndangUndang Nomor 14 Tahun 2008 ini diadopsi dan menjadi "roh" Undang-Undang Nomor 12 Tahun 2011 tentang Pembentukan Peraturan Perundang-undangan. Hal tersebut dikarenakan, dalam setiap ketentuan mengenai tujuan dari keterbukaan informasi publik sangat jelas disebutkan bahwa masyarakat berhak dilibatkan dalam proses pengambilan kebijakan publik. Asas keterbukaan yang menjadi "entry point" partisipasi masyarakat dalam setiap proses pembentukan produk hukum dicantumkan sebagai salah satu asas pembentukan peraturan perundang-undangan yang baik. Artinya, jika suatu peraturan perundang-undangan dibentuk tanpa adanya asas keterbukaan maka peraturan perundangundangan/produk hukum tersebut bukan suatu peraturan perundang-undangan/produk hukum yang baik. 


\section{Simpulan}

1. Implikasi yuridis terhadap disharmonisasi pemberian jangka waktu hak pakai bagi Warga Negara Asing dalam konstruksi hukum positif di Indonesia adalah ketidakpastian hukum bagi WNA dan bertentangan dengan asas-asas pembentukan peraturan perundangundangan, yang salah satunya menganut tentang asas kesesuaian antara jenis dan materi muatan yang menjadi hal penting dalam pembentukan suatu peraturan perundang-undangan, ketidakpastian hukum dan pertentangan asas tersebut muncul akibat adanya inkonsistensi pemberian jangka watu hak pakai dan dualisme proses perpanjangan dan pembaruan hak.

2. Rekonstruksi pemberian jangka waktu hunian bagi Warga Negara Asing dalam konstruksi hukum positif di Indonesia di masa yang akan mendatang dilakukan dengan melakukan beberapa perubahan dan/atau penyesuaian pengaturan mengenai pemberian jangka waktu hak pakai bagi WNA sebagai hunian yang diberikan selama 25 (dua puluh lima) tahun serta pengaturan diberlakukannya prosedur pembaruan tanpa mengenal kembali prosedur perpanjangan dalam Pasal 7 PP Nomor 103 Tahun 2015.

\section{DAFTAR PUSTAKA}

\section{Buku}

Bachri. Survey Faktor-Faktor Non Ekonomi yang Mempengaruhi Iklim Investasi di Sul-Sel, Kajian Ekonomi Regional Sulawesi Selatan. Triwulan II, 2007.

Kusumaatmadja, Mochtar. Konsep Hukum Dalam Pembanguna. Bandung: PPSWN Alumni, 2002.

Parlindungan, A.P. “Beberapa Konsep tentang Hak-hak Atas Tanah". Majalah CSIS Edisi Tahun XX Nomor 2. Jakarta: 1991. Sidharta. Menuju Harmonisasi System Hukum sebagai Pilar Pengelolaan Wilayah Pesisir Indonesia. Jakarta: Bapenas, 2005.
Siregar, Tampil Anshari. Pendalaman Lanjutan Undang-Undang Pokok Agraria. Cetakan Pertama. Medan: Pustaka Bangsa Press, 2005.

Soehino. Ilmu Negara. Yogyakarta: Liberti, 1980.

Sumardjono, Maria. Kebijakan Pertanahan Antara Regulasi dan Implementasi. Jakarta: Buku Kompas, 2009.

\section{Disertasi}

Suhartono. "Harmonisasi Peraturan Perundang-undangan dalam Pelaksanaan Anggaran Belanja Negara". Desertasi Ilmu Hukum. 
Jakarta: Fakultas Hukum Universitas

Indonesia, 2011. Tidak Dipublikasikan.

\section{Jurnal}

Setiadi, Wacipto. "Proses Pengharmonisasian sebagai Upaya Untuk Memperbaiki Kualitas Peraturan Perundangundangan”. Jurnal Legislatif Indonesia, Vol. 4, (Juni 2007): 48.

\section{Peraturan Perundang-undangan}

Undang-Undang Dasar Negara Republik Indonesia Tahun 1945.

Undang-undang Nomor 5 Tahun 1960 tentang Peraturan Dasar Pokok-Pokok Agraria.
Undang-undang Nomor 12 Tahun 2011 tentang Pembentukan Peraturan Perundang-Undangan.

Undang-undang Nomor 20 Tahun 2011 tentang Rumah Susun.

Undang-undang Nomor 1 Tahun 2011 tentang Perumahan dan Kawasan Permukiman.

Peraturan Pemerintah Nomor 40 Tahun 1996 tentang Hak Guna Usaha, Hak Guna Bangunan dan Hak Pakai atas Tanah.

Peraturan Pemerintah Nomor 103 Tahun 2015 tentang Pemilikan Rumah Tempat Tinggal atau Hunian Oleh Orang Asing yang Berkedudukan di Indonesia. 